\title{
The study of sustainability in administration: A research of the hot topics published in the last decade
}

\author{
Luciana Flores Battistella ${ }^{1}$, Márcia Zampieri Grohmann ${ }^{1,2 \star}$ and Aline Velter ${ }^{1}$ \\ ${ }^{1}$ Federal University of Santa Maria - Brazil. \\ ${ }^{2}$ Rua Floriano Peixoto, 1184 - Sala 502. CEP 97015-372, Santa Maria - RS - Brazil.
}

Accepted 17 May, 2013

\begin{abstract}
The aim of this study was to examine publications on the topic of sustainability and to identify key areas of administration that are being studied with sustainability. The survey was conducted in the Web of Science database, searching to identify the main subject areas, authors, types of documents, titles of the sources, the year of the publications, institutions, funding agencies, countries and languages of these publications, as well as to discover the "hot topics" of administration when combined with the topic of sustainability. Data analysis was based on the calculations of $h-b$ and $m$ indexes of Banks (2006). According to the results of this study almost $73 \%$ of the publications are in article format (papers), among the authors with the highest number of publications there is no author that has an outstanding quantity of publications, the institution with the highest number of publications is the University Of British Columbia in Canada. Among the 20 institutions that have published the most about this subject, most institutions (11) and also the most significant in terms of total number of publications are North American totaling 1,173. As the number of institutions and the number of publications have demonstrated the bulk of publications are concentrated in the United States totaling 5,251 . The English language is predominant as $96 \%$ of the publications are written in this language. Among the sources of the publications, the highlight was the Journal of Ecological Economics with 428 publications and the subject area that had the highest number of publications is environmental sciences. Among the 20 topics related to sustainability, the following were classified as "hot topics": management, production process, consumption, innovation, public management, business,
\end{abstract} stakeholders, and communication.

Key words: Sustainability, management, bibliometric research.

\section{INTRODUCTION}

Efforts to attend the needs of the growing population in an interconnected but unequal and human-dominated world are mining the essential life support system of the planet. The extraordinary complexity of challenges that lie ahead is suggested by the emerging interactions between global environmental changes and the profound ongoing changes in economical and social life (Kates et al., 2000).

The combination of satisfaction of the basic human needs with the preservation of the life support system of the planet requires a global effort to stop the existing progress and make a transition towards sustainability. The significant response to this challenge to the scientific community began to emerge from a variety of regional and global programs of environmental research (United Nations Educational, Scientific and Cultural Organization - UNESCO, United Nations Conference on Environment and Development (UNCED), among others); through the 
academic world of science, including individual reports from African, Brazilian and American academies (e.g. the Fifth General Conference of the African Academy of Sciences and the United States Business Council for Sustainable Development); from independent scholar and scientist networks (Kates, 1994; Funtowicz and O'Connor, 1999; Grubler, 2000; Moore III, 2000; O'Riordan, 2000); and the Friibergh Workshop on the Sustainability Science in 2000.

Above all, a response began to emerge from science itself and the growing acknowledgement of several disciplines, a need for synthesis and integration - needs that are being reflected in many new efforts of multidisciplinary research and institutions (Global Change Newsletter, 1999; National Science Board, 2000). According to Kate et al. (2000) these diverse scientific efforts to further the objectives of a transition to sustainability - satisfaction of human needs while preserving life support systems - are leading to the developing of a new scientific field of sustainability.

With the objective to analyze publications on the topic of sustainability on the Web of Science database, the article by Madruga and Silva (2008) searched the spatiotemporal location of these publications, as well as identifying "hot topics". In their findings, management/ administration was detected as one of the "hot topics" in the study of sustainability.

Guided by the emergence and importance of the studies related to sustainability proposed by Kate et al. (2000) and by the findings in the study of Madruga and Silva (2008), the objective of this study was to deepen knowledge about publications in the area of sustainability in the period of 2000 to 2010 , as well as to identify which topics of administration are considered "hot topics" when studied together with sustainability. For this purpose, data collection was performed on the Web of Science database.

The article is structured in six sections: Introduction; Review on the study of sustainability where the objective was to identify the evolution of its concept and some studies in administration; research methods; results; conclusion and references.

\section{THE STUDY OF SUSTAINABILITY}

The most widespread definition of sustainability is that of the Brundtland Commission (World Commission on Environment and Development, 1987) which considers that sustainable development must meet the needs of the existing generation without compromising the needs of future generations. This definition clarifies one of the basic principles of sustainability - long-term vision - as the interests of future generations must be analyzed. For better understanding of the concept of sustainability, Table 1 shows the main events in the evolution of the concept of sustainability.
Since its initial conception in the Brundtland Report, the definition of sustainability has been criticized because it presents ambiguity and gaps (Chaharbaghi and Willis, 1999; Hauschild et al., 1999). According to GonçalvesDias et al. (2007), sustainability covers a range of concepts and practices that include: ensure perpetual human survival (Farrell, 1995; Ehrenfeld, 2001); protect threatened ecosystems (Farrell, 1995; Mosovsky et al., 2000; Howarth and Hadfield, 2003); recognize human dependence on the ecosystems (Farrell, 1995; Ehrenfeld, 2001); guarantee all people access to meet their needs and enjoy freedom to develop their potential (Farrell, 1995; Ehrenfeld, 2001; Howarth and Hadfield, 2003); allocate resources equally among people, including future generations (Mosovsky et al., 2000; Ehrenfeld, 2001); and involve all individuals and institutions in order to achieve sustainability (Ehrenfeld, 2001).

The broad concept of sustainability eventually extended its borders and met other academic traditions, be it in the area of social politics, cultural studies and also in the field of administration. Administration as a science has been resizing and adjusting to the constant needs arising from contexts and era that marked its trajectory in the world, that is, these era were always marked by relevant administrative activities in their distinct periods.

The term sustainability is increasingly present in academic studies related to administration (Costanza et al., 1991; Gladwin et al., 1995; Hawken, 1993; Schmidheiny, 1992; World Commission on Environment and Development, 1987) and in the practice of the business environment. Sharma et al. (2010) verified some topics of administration that study and use sustainability in their business practices. The authors discuss the study of marketing and sustainable environment emphasizing the understanding of the environmental conscience of the consumer, making reference to authors who do research on the topic (Antil, 1984; Kinnear et al., 1974). There is also discussion on the waste and indicators in production, production process and supply chain with the support of the studies by Guide and Van Wassenhove (2001), Guide et al. (2003), and among others.

In accordance with the study of Madruga and Silva (2008) which used the h-b index created by Banks (2006) while researching the topic of sustainability, one of the areas which showed strong correlation with the topic of sustainability was administration / management, presenting a positive correlation of 0.992 and $m$-index of the combination of sustainability and management of 2.625. Their research also revealed the multidisciplinary nature of sustainability, as its concept encompasses other issues (environmental, social, etc.). The findings of Madruga and Silva (2008) encouraged the research of sustainability with the topics of administration.

\section{METHOD}

This article was developed from a bibliometric research perspective 
Table 1. Evolution of the concept of sustainability.

\begin{tabular}{|c|c|c|}
\hline Date & $\begin{array}{l}\text { Events, facts and milestones that } \\
\text { built the concept }\end{array}$ & Objectives, implications and concepts of sustainability \\
\hline 1972 & $\begin{array}{l}\text { Stockholm Conference (First World } \\
\text { Conference about Man and the } \\
\text { Environment). }\end{array}$ & $\begin{array}{l}\text { Insertion of the environmental dimension into the international } \\
\text { political agenda, conditioning and placing restrictions on the } \\
\text { economic model and use of natural resources. The term } \\
\text { sustainable development emerges in the social, economical, } \\
\text { political, cultural and environmental aspects. }\end{array}$ \\
\hline 1975 & $\begin{array}{l}\text { Belgrade Meeting sponsored by } \\
\text { UNESCO }\end{array}$ & $\begin{array}{l}\text { The main theme of the meeting emphasized the need for a new } \\
\text { global ethic which would lead to the eradication of poverty, } \\
\text { hunger, illiteracy, pollution and human domination and } \\
\text { exploitation. }\end{array}$ \\
\hline 1980 & $\begin{array}{l}\text { Publication of the document "World } \\
\text { Strategy for Conservation. The } \\
\text { Conservation of Living Resources for } \\
\text { Sustainable Development." by the } \\
\text { United Nations Environment } \\
\text { Programme (UNEP) }\end{array}$ & $\begin{array}{l}\text { Reaffirmation of a critical view of the development model of } \\
\text { industrialized countries. }\end{array}$ \\
\hline 1987 & $\begin{array}{l}\text { Brundtland Report is released at a UN } \\
\text { Event. }\end{array}$ & $\begin{array}{l}\text { Construction of the concept which states "Sustainable } \\
\text { development is development that meets present needs without } \\
\text { compromising the ability of future generations to meet their own } \\
\text { needs." }\end{array}$ \\
\hline 1992 & $\begin{array}{l}\text { The ECO } 92 \text { event drafts a document } \\
\text { entitled Agenda } 21 \text { in Rio de Janeiro, } \\
\text { Brazil. }\end{array}$ & $\begin{array}{l}\text { Agenda } 21 \text { is a proposal for actions in favor of sustainable } \\
\text { development involving all segments of society in the formulation of } \\
\text { policies and practices for sustainability from a systemic } \\
\text { perspective with global reach. }\end{array}$ \\
\hline 1992 & $\begin{array}{l}\text { Drafting of the Earth Charter also } \\
\text { known as The Rio Declaration at the } \\
\text { International Forum of Non- } \\
\text { Governmental Organizations of the } \\
\text { Global Forum }\end{array}$ & $\begin{array}{l}\text { Call for the adoption of the principles of the Earth Charter } \\
\text { consisting of } 10 \text { commitments. }\end{array}$ \\
\hline 1997 & $\begin{array}{l}\text { Kyoto Protocol (in vigor from } 2005 \text { to } \\
2012 \text { ) }\end{array}$ & $\begin{array}{l}\text { International treaty with more stringent commitments to reduce } \\
\text { gases that exacerbate the greenhouse effect considered by most } \\
\text { scientific research as the cause of anthropogenic global warming. }\end{array}$ \\
\hline 2002 & $\begin{array}{l}\text { Event sponsored by the World Summit } \\
\text { on Sustainable Development in South } \\
\text { Africa (Rio 10+) }\end{array}$ & $\begin{array}{l}\text { Evaluation of proposals for the implementation of the conclusions } \\
\text { of the Rio } 92 \text { event, that is, how to put into practice the concept of } \\
\text { sustainability on the planet. }\end{array}$ \\
\hline
\end{tabular}

with the objective of increasing awareness in the study area related to sustainability and determining which topics studied in administration together with sustainability are being further researched and which are most relevant.

According to Fonseca (1986), bibliometry is a quantitative and statistical technique for measuring the rates of production and the dissemination of scientific knowledge. For Araújo (2006) the most important area of bibliometry is citation analysis which contributes to the development of science, provides the necessary recognition of a scientist by his colleagues, establishes property rights and priority of the scientific contribution of an author, are important information sources and helps judge the habits of information and show literature which is essential to the work of scientists (Foresti, 1989).
Data analysis was supported by qualitative and quantitative research approaches. In qualitative terms, the issues addressed in the researched publications were analyzed. As regards content, key words and topic relevance were analyzed. As for the quantitative data the following variables were investigated: total number of publications, authors, subject areas, types of documents, title of sources, year of publications, institutions, funding agencies, languages, countries and analysis of the number of times each publication was cited through the $h-b$ index and the $m$ index.

In accordance to Hirsch (2005) quantification of the impact and relevance of individual scientific research is often required for evaluating researchers and comparing purposes. From this principle Hirsch presented the h-index in his research called "An index to quantify an individual's scientific research output". 


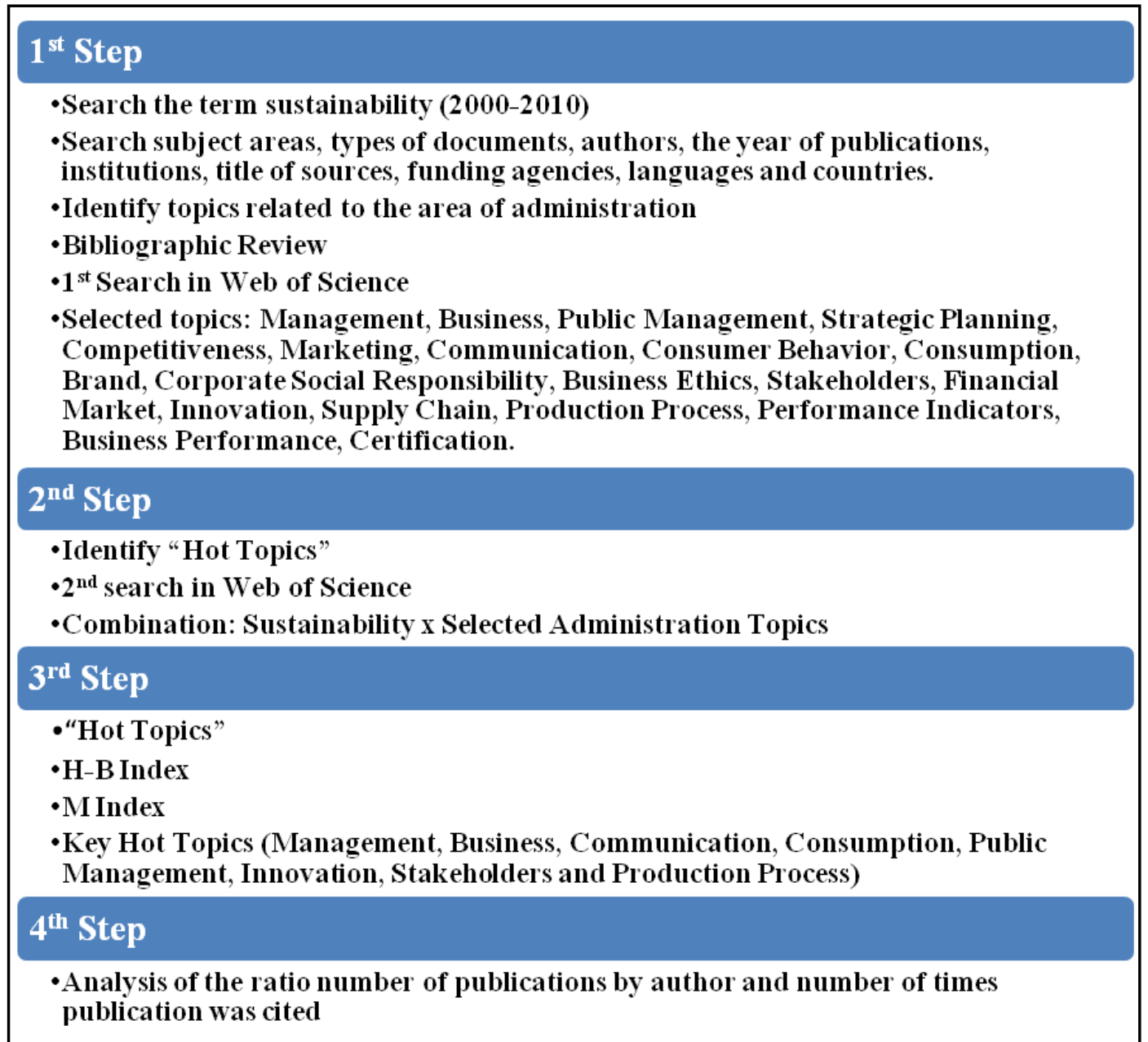

Figure 1. Steps of the research.

Afterwards, Banks (2006) contributed with the $h-b$ index, an extension of the h-index. This index, in turn, is obtained through the number of citations of a topic or combination in a given period listed in descending order of citations. This is found in publications that have obtained a number of citations equal to or greater than their ranking position. Banks (2006) also explains the calculation of the $m$-index, which is obtained by dividing $h-b$ index by the period of years that one wishes to obtain information $(n)$.

The following considerations made by Banks (2006) were used to analyze the $\mathrm{h}-\mathrm{b}$ and $\mathrm{m}$-indexes:

- When $0<m \leq 0.5$, the topic/combination may be of interest for researchers in a specific research field, where the field encompasses a small community;

- When $0.5<m \leq 2$, the topic/combination is likely to be a "hot topic" as a research area, where the field is too large or the topic/combination presents very interesting characteristics; and - When $m \geq 2$, it is a unique topic/combination where the consequences have a greater scope than its own research area. It is probably a topic/combination with application effects or unique characteristics.

\section{Steps for the collection of data}

The collection of data used in this research was done through the
Web of Science database of the ISI Citation Index which was first published inprint in 1963 with citation data beginning from 1961 (Garfield, 1963). According to Bar-llan (2010), in September 2008 Thomson Reuters added indexed citations of conference proceedings in the area of Science, Social Sciences and Human Sciences to the ISI Web of Science. Web of Science provides direct access to retrospective multidisciplinary flow of information of approximately 8,700 of most prestigious, high impact research journals in the world (Thomson Scientific, 2010). The references of all indexed items are extracted and the cited reference interface lists all citation to works of an author, regardless of whether the cited items are indexed by Web of Science or not (Bar-llan, 2008).

As shown in Figure 1, the research was divided into 4 steps. Firstly the term sustainability was typed as a topic in the search field for the period of 2000 to 2010 (10.5 years). Thus the following information arose: total number of publications, subject areas, types of documents, authors, title of sources, institutions, funding agencies, the year of publication, languages and countries. With the result of this first search, it was also possible to investigate the main articles related to the area of administration and thus list along with the literature studied, 20 subjects to be combined with the term sustainability.

In the second step, there was a second search in the system, combining each of the topics related to the area of administration with the term sustainability in the same period of time of the first search (2000-2010). Afterwards, there was a classification of the 
Table 2. Subject areas in the study of sustainability.

\begin{tabular}{lc}
\hline Subject areas & Number of publications \\
\hline 1. Environmental Sciences & 3,572 \\
2. Environmental Studies & 2,248 \\
3. Ecology & 1,920 \\
4. Economics & 1,270 \\
5. Engineering, Environmental & 1,160 \\
6. Agriculture, Multidisciplinary & 998 \\
7. Water Resources & 988 \\
8. Energy and Fuels & 738 \\
9. Planning and Development & 720 \\
10. Agronomy & 703 \\
11. Geography & 670 \\
12. Forestry & 643 \\
13. Public, Environmental and Occupational Health & 631 \\
14. Soil Science & 580 \\
15. Engineering, Civil & 565 \\
16. Management & 459 \\
17. Geosciences, Multidisciplinary & 449 \\
18. Marine and Freshwater Biology & 449 \\
19. Engineering, Chemical & 447 \\
20. Fisheries & 413 \\
\hline
\end{tabular}

publications and identification of the "hot topics".

Lastly, an analysis was made on the ratio of the number of publications per author and the number of times the author was cited in order to ascertain whether the quantity published by the author is directly related to the relevance of its scientific output. For this reason, for each combination considered a "hot topic", the 10 most published authors and the 10 most cited publications were selected. According to Hirsch (2005) the total number of articles published measures the productivity of the author, but it does not measure the importance and/or impact of their publications. The impact of the publications is measured by the number of citations that each publication obtains being measured using the $\mathrm{h}$-index.

\section{ANALYSIS AND DISCUSSION}

\section{The study of sustainability in the last decade}

At first, the term sustainability was searched in Web of Science. As a result, 18,535 publications were found, which were divided in this study in: subject areas, authors, types of documents, title of the sources, the year of publications, institutions, funding agencies, languages and countries.

In relation to the subject areas which cover the study of sustainability, the top twenty were found to have obtained the highest number of publications as shown in Table 2. Analyzing the results and theoretical reference discussed earlier, multidisciplinarity is evident in the study concerning sustainability. Fields of study related to ecology, engineering, agronomy, economics, management, geography, etc. also arise. The phenomenon of multidisciplinarity can be supported by the comprehension of the concept of sustainability, which according to Sachs (1993) involves the social, environmental, economic, spatial and cultural dimensions.

The following are the top 20 authors who have the highest published articles on sustainability, excluding unsigned publications: Chen G.Q. (22), Haberl H. (22), Scholz R.W. (21), Chen B. (20), Dincer I. (20), Krausmann F. (20), Bastianoni S. (19), Folke C. (19), Zhang Y. (18), Yang Z.F. (17), Berkes F. (16), Botsford L.W. (15), Cairns J. (15), O'Riordan T. (15), Scott D. (15), Bakshi B.R. (14), Brent A.C. (14), Giampietro M. (14), Hammond G.P. (14), and Hilborn R. (14). It is observed that there is parity among the authors concerning the number of publications.

Among the 18,535 publications found, 13,495 (almost $73 \%$ of the total) are articles, 2,152 are annals, 1,114 are reviews, 868 are editorial material and 480 are book reviews. As for the title of the sources there was a great diversification of the study fields, such as: ecology, management, agriculture, technology, among others. The 20 sources that most published in the period investigated released 73 to 422 publications: Ecological Economics (428), Journal of Cleaner Production (306), Forest Ecology and Management (186), Agriculture Ecosystems and Environment (169), International Journal of Sustainable Development and World Ecology (169), Energy Policy (165), Journal of Environmental Management (149), Water Science and Technology (134), Sustainable Development (129), Journal of Sustainable 


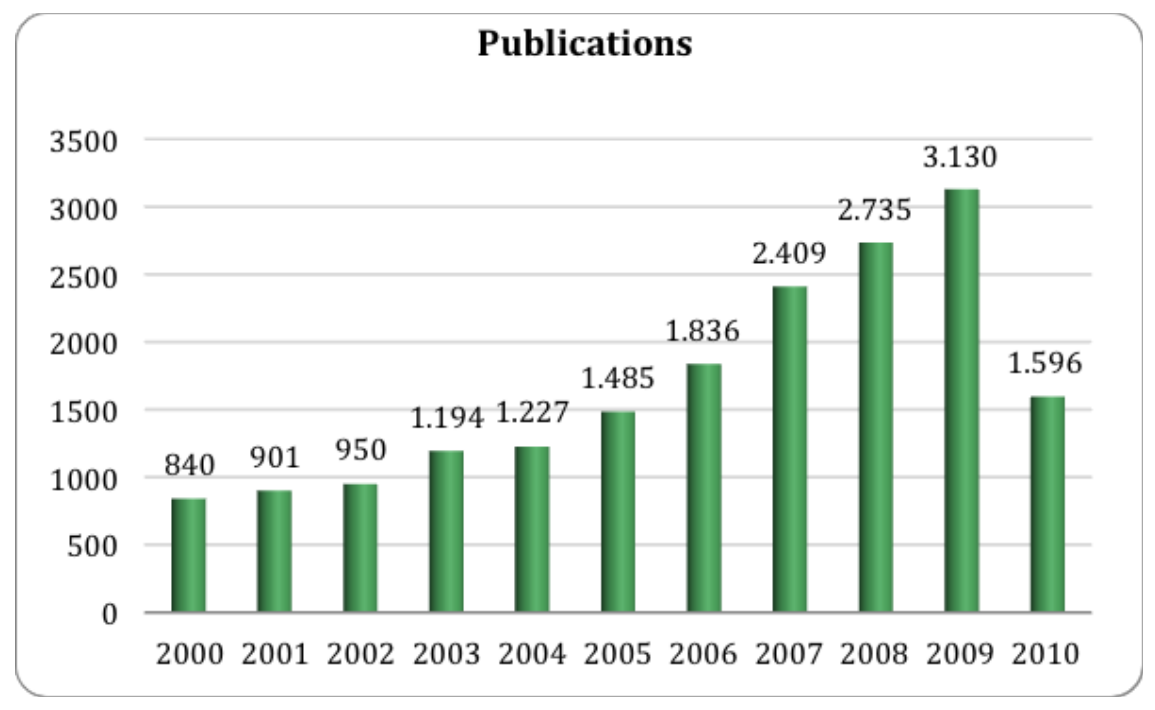

Figure 2. Publications per year.

Agriculture (125), Environmental Management (114), Ecological Modelling (102), Journal of Business Ethics (95), Australian Journal of Experimental Agriculture (91), Proceedings of the National Academy of Sciences of the United States of America (87), Renewable and Sustainable Energy Reviews (87), Environmental Science and Technology (81), Agricultural Systems (75), Forestry Chronicle (75) Landscape and Urban Planning (74).

Observing the historical timeline of publications involving the term sustainability (Figure 2), there was a gradual increase in the last decade, intensifying in the last 5 years. The evolution of research in this area may be justified by greater awareness of society in face of social-environmental issues which are gaining increasing prominence in various media (Dias, 2008).

The following 20 institutions with the most publications related to the topic of sustainability were found: 11 North American institutions totaling 1,173 publicationsUniversity of Washington (130), United States Department of Agriculture - Agricultural Research Service (126), University of Florida (117), University of California, Davis (112), University of California, Berkeley (111), University of Wisconsin (102), Cornell University (98), Arizona State University (96), Harvard University (96), University of Michigan (96) Ohio State University (89); 4 Australian institutions totaling 420 publications University of Queensland (117), Australian National University (107), University of Melbourne (100), Monash University (96); 2 Canadian institutions totaling 340 publications - University of British Columbia (203) University of Toronto (137); 1 Chinese institution totaling 191 publications - Chinese Academy of Sciences, 1 Dutch institution totaling 157 publications - Wageningen University and Research Center; and 1 French institution totaling 121 publications - French National Institute for Agricultural Research.
In relation to the funding agencies that cover sustainability, the top 10 with the highest number of publications were: National Natural Science Foundation of China (57), National Science Foundation (54), European Commission (34), The United States of America (31), Chinese Academy of Science (20), European Union (19), NSF - National Science Foundation (19), National Basic Research Program of China (17), CNPQ - Conselho Nacional de Desenvolvimento Científico e Tecnológico (The National Council for Scientific and Technological Development) (14) and EPSRC - Engineering and Physical Sciences Research Council (13).

Regarding the number of publications by country (Figure 3) the United States leads the ranking of most published with 5,251, followed by England $(2,091)$, Australia (1,533), Canada (1,369), Germany (975), The Netherlands (837), China (692), France (620), Italy (520), Brazil (519), India (488), Sweden (454), Switzerland (426), Japan (373), Scotland (366), South Africa (345), New Zealand (297), Austria (237) and Belgium (235). From the findings it may be inferred that these are the countries in which the institutions publish more and invest more in research in the field of sustainability.

According to the list of the countries that have the most published work on the topic of sustainability (United States, England, Australia and Canada), the English language stands out among other languages with 17,666 publications, nearly $96 \%$ of the total. Following is the German language with 270 publications, Spanish with 177, Portuguese with 163 and French with 81 publications.

\section{The study of sustainability in administration}

At this stage of the research, publications on sustainability related to distinct areas in the study of 


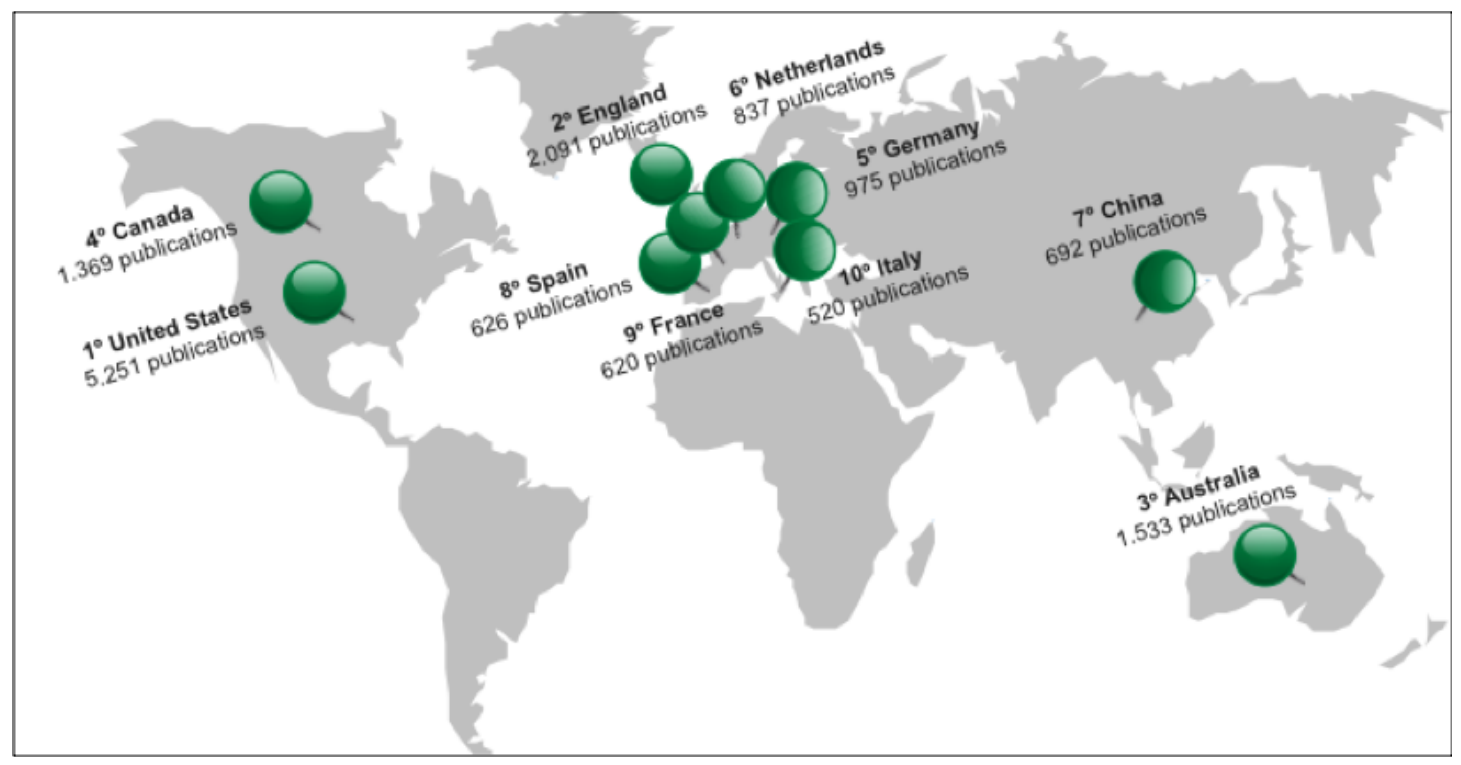

Figure 3. Top 10 countries with the highest number of publications on sustainability.

Table 3. Selected topics for the study related to administration.

\begin{tabular}{llc}
\hline Topics & Total number of publications \\
\hline 1st. & Communication & $>100,000$ \\
2nd. & Consumption & $>100,000$ \\
3rd. & Management & $>100,000$ \\
4th. & Production Process & 99,986 \\
5th. & Business & 57,510 \\
6th. & Innovation & 39,336 \\
7th. & Public Management & 20,368 \\
8th. & Marketing & 18,640 \\
9th. & Brand & 14,488 \\
10th. & Financial Market & 12,909 \\
11th. & Stakeholders & 11,110 \\
12th. & Supply Chain & 10,231 \\
13th. & Business Performance & 8,818 \\
14th. & Performance Indicators & 8,402 \\
15th. & Certification & 7,954 \\
16th. & Competitiveness & 6,771 \\
17th. & Consumer Behavior & 5,476 \\
18th. & Strategic Planning & 3,620 \\
19th. & Business Ethics & 2,053 \\
20th. & Corporate Social Responsibility & 1,614 \\
\hline
\end{tabular}

administration were investigated. With a brief bibliographic review of the material found in the Web of Science database, 20 topics were selected associated to the area of administration, which showed good incidence of studies with the sustainability topic. The selected topics were: Management, Business, Public Management, Strategic Planning, Competitiveness, Marketing, Communication, Consumer Behavior, Consumption,
Brand, Corporate Social Responsibility, Business Ethics, Stakeholders, Financial Market, Innovation, Supply Chain, Production Process, Performance Indicators, Business Performance and Certification. Table 3 shows the ranks of the 20 topics according to the number of publications:

Subsequently, a combination of each topic listed earlier with sustainability was done. The total number of 
Table 4. Sustainability in administration.

\begin{tabular}{llccc}
\hline Topics & Total number of publications & h-b index & m-index \\
\hline 1st. & Management & 6,332 & 66 & 6.29 \\
2nd. & Consumption & 1,156 & 31 & 2.95 \\
3rd. & Production Process & 895 & 33 & 3.14 \\
4th. & Business & 836 & 24 & 2.29 \\
5th. & Stakeholders & 781 & 23 & 2.19 \\
6th. & Innovation & 721 & 25 & 2.38 \\
7th. & Public Management & 665 & 25 & 2.38 \\
8th. & Communication & 441 & 21 & 2.00 \\
9th. & Performance Indicators & 328 & 20 & 1.90 \\
10th. & Supply Chain & 225 & 15 & 1.43 \\
11th. & Certification & 221 & 17 & 1.62 \\
12th. & Marketing & 204 & 16 & 1.52 \\
13th. & Business Performance & 190 & 17 & 1.62 \\
14th. & Corporate Social Responsibility & 169 & 11 & 1.05 \\
15th. & Strategic Planning & 167 & 14 & 1.33 \\
16th. & Competitiveness & 166 & 11 & 1.05 \\
17th. & Financial Market & 149 & 11 & 1.05 \\
18th. & Business Ethics & 46 & 5 & 0.48 \\
19th. & Brand & 45 & 9 & 0.85 \\
20th. & Consumer Behavior & 42 & 8 & 0.76 \\
\hline
\end{tabular}

publications for each combination was also calculated (topic related to administration $\times$ sustainability), the $\mathrm{h}$ index and the m-index (Table 4). The results were listed according to the total number of publications of each combination, although it is important to observe that some topics that individually have a significant number of publications (Communication, Financial Market and Brand), when researched with the topic of sustainability, the number of publications becomes less significant compared to other combinations. It may also be noticed that some topics have a lower number of individual publications (Stakeholders, Performance Indicators and Certifications), and when researched with the topic of sustainability, it becomes more significant compared to other combinations.

With the calculation of the $\mathrm{h}$-index and the m-index it is possible to measure the performance of the topics/ combinations investigated based on their number of citations (Kelly and Jennions, 2006). Based on considerations of Banks (2006) on the h-b and mindexes, it is possible to classify as "hot topics" combinations of sustainability with: management (6.29); production process (3.14); consumption (2.95); innovation (2.38); public management (2.38); business (2.29); stakeholders (2.19) and communication (2.00). The other combinations by presenting $m>0.5$ may be considered as emerging "hot topics" as research areas.

Based on research conducted in the Web of Science database, the top 10 authors with the most publications were selected for the combinations considered "hot topics" (management, production process, consumption, innovation, public management, business, stakeholders and communication). It was also investigated among these researchers, those who appear as authors of the 10 most cited publications for each combination (Table 5).

Table 5 clearly elaborates the ratio of the number of publications per authors with the number of times each author (publication) was cited. Based on Table 5, it is possible to observe that the number of publications is not related to the efficiency of the author (number of times it was cited). Only authors such as Folke C. (management), Burger J.A. and Garcia S.M. (public management), and Butler B.S. (communication) of the top 10 authors with the most publications are on the list of the 10 most cited publications as researchers.

\section{FINAL CONSIDERATIONS}

According to Madruga and Silva (2008), the findings of this study demonstrated the multidisciplinary nature of sustainability. The research also showed that in the last decade (2000-2010) the study of sustainability is increasing year after year. This increased interest in studying the sustainability theme is parallel to the growth of environmental concern of organizations and society.

The information obtained in the Web of Science database indicated that almost $73 \%$ of the publications are in article format (papers), among the authors with the 
Table 5. Ratio of authors with the most publications and the most cited publications.

\begin{tabular}{|c|c|c|}
\hline Topics & Authors with the most publications & Most cited publications \\
\hline Management & $\begin{array}{l}\text { Berkes, F. (16); Folke, C. (15); Christie, P. (12); } \\
\text { Hilborn, R. (12); Botsford, L.W. (11); Lodge, G.M. } \\
\text { (11); Scholz, R.W. (11); Deckers, J. (10); Govaerts, } \\
\text { B. (10); and Ridley, A.M. (10). }\end{array}$ & $\begin{array}{l}5^{\circ}{ }^{2} \text { Lambin E.F., Turner B.L., Geist H.J., Folke C., et al. } \\
\text { (2001). The causes of land-use and land-cover change: } \\
\text { moving beyond the myths, Global Environmental Change- } \\
\text { Human and Policy Dimensions, v. 11, p. 261-269. (284) } \\
\text { 10․ Hughes T.P., Bellwood D.R., Folke C., et al. (2005). } \\
\text { New paradigms for supporting the resilience of marine } \\
\text { ecosystems, Trends in Ecology and Evolution, v. 20, p. 380- } \\
\text { 386. (172) }\end{array}$ \\
\hline Consumption & $\begin{array}{l}\text { Chen, G.Q. (12); Chen, B. (10); Krausmann, F. } \\
\text { (10); Haberl, H. (8); Bakshi, B.R. (7); Erb, K.H. (7); } \\
\text { Yang, Z.F. (7); Fischer-Kowalski, M. (6); Verbeke, } \\
\text { W. (6); and Browne, D. (5). }\end{array}$ & - \\
\hline $\begin{array}{l}\text { Production } \\
\text { Process }\end{array}$ & $\begin{array}{l}\text { Bastianoni, S. (7); Dewulf, J. (7); Haberl, H. (7); } \\
\text { Van Langenhove, H. (7); Krausmann, F. (6); Van } \\
\text { Ittrrsum, M.K. (5); Feijoo, G. (4); Gonzalez-Garcia, } \\
\text { S. (4); Hungerbuhler, K. (4); and Marchettini, N. (4) }\end{array}$ & - \\
\hline Business & $\begin{array}{l}\text { Robert, K.H. (5); Lenzen, M. (4); Van Marrewijk, M. } \\
\text { (4); Broman, G. (3); Brown, H.S. (3); Danes, S.M. } \\
\text { (3); Genaidy, A.M. (3); Khan, S. (3); Kolk, A. (3); } \\
\text { and Konrad, A. (3). }\end{array}$ & - \\
\hline Stakeholders & $\begin{array}{l}\text { Burger, J. (15); Decker, D.J. (14); Loisel, P. (14); } \\
\text { Carter, R. (13); Van Ittersum, M.K. (12); Van } \\
\text { Keulen, H. (12); Abma, T.A. (11); Scholz, R.W. } \\
\text { (11); Ouma, J. (10); and Gochfeld, M. (10). }\end{array}$ & - \\
\hline Innovation & $\begin{array}{l}\text { Geels, F.W. (7); Smith, A. (5); Vezzoli, C. (5); } \\
\text { Tukker, A. (4); Anastas, P.T. (3); Lovell, H. (3); } \\
\text { Partidario, P.J. (3); Raven, R.P.J.M. (3); Van } \\
\text { Keulen, H. (3); and Vergragt, P.J. (3). }\end{array}$ & - \\
\hline & Sinclair, A.J. (5); Kneeshaw, D.D. (4); Messier, C. & $\begin{array}{l}4^{\circ} \text {. Schoenholtz S.H., Van Miegroet H., Burger J.A. (2000). } \\
\text { A review of chemical and physical properties as indicators of } \\
\text { forest soil quality: challenges and opportunities, Forest } \\
\text { Ecology and Management, v. } 138, \text { p. } 335-356 .(68)\end{array}$ \\
\hline $\begin{array}{l}\text { Public } \\
\text { Management }\end{array}$ & $\begin{array}{l}\text { (4); Burger, J.A. (3); Duda, A.M. (3); Garcia, S.M. } \\
\text { (3); Hull, R.B. (3); Preuss, L. (3); Sansom, K. (3); } \\
\text { and Abebe, Y. (2). }\end{array}$ & $\begin{array}{l}7^{\circ} \text {. Garcia S.M., Staples D.J. (2000). Sustainability } \\
\text { reference systems and indicators for responsible marine } \\
\text { capture fisheries: a review of concepts and elements for a } \\
\text { set of guidelines, Marine and Freshwater Research, v. 51, p. } \\
385-426 \text {. (57) }\end{array}$ \\
\hline Communication & $\begin{array}{l}\text { Castillo, A. (3); Hilty, L.M. (3); Verbeke, W. (3); } \\
\text { Arlinghaus, R. (2); Barr, S (2); Branch, G.M. (2); } \\
\text { Butler, B.S. (2); Carusone, S.C. (2); Davies, G.P. } \\
\text { (2); and Dye, A.H. (2) }\end{array}$ & $\begin{array}{l}\text { 6․ Butler B.S. (2001). Membership size, communication } \\
\text { activity, and sustainability: a resource-based model of online } \\
\text { social structures, Information Systems Research, v. 12, p. } \\
\text { 346-362. (68) }\end{array}$ \\
\hline
\end{tabular}

${ }^{1}$ number of publications by author; ${ }^{2}$ position of the publication according to the number of citations; ${ }^{3}$ number of citations.

highest number of publications there is no author that has an outstanding quantity of publications, the institution with the highest number of publications is the University Of British Columbia in Canada. However, among the 20 institutions that have published the most about this subject, most institutions (11) and also the most signifycant in terms of total number of publications are North American totaling 1,173. As the number of institutions and the number of publications have demonstrated the bulk of publications are concentrated in the United States totaling 5,251. Also corroborating with the previous information, the English language is predominant as $96 \%$ of the publications are written in this language. Among the sources of the publications, the highlight was the Journal of Ecological Economics with 428 publications and the subject area that had the highest number of publications is environmental sciences. It is not surprising that the concentration of the work about this theme is in the United States because is in this country that are the principal investigators of this subject.

As "hot topics", it was noticed that Management, Consumption, Production Process, Business, Stakeholders, Public Management and Communication were more relevant with the study of sustainability. It was also 
ascertained that the authors who have the highest number of publications are not necessarily the most relevant to academic knowledge in terms of number of times they were cited in other papers. These subjects with sustainability theme are increasingly evident in empirical studies, both investigating the buying behavior of consumers, as exploring environmental practices in the company's business.

It is suggested for future research the use of other topics of administration which may be considered "hot topics" with the study of sustainability as this article was limited to the choice of subjects as perceived by researchers and a brief bibliographic review on the subject. Another suggestion is regarding the period of years investigated, which may cover a longer time period than the one in this study. Lastly, according to Madruga and Silva (2008), this research can be done using other database in order to complement, compare or substitute the results found in this study.

\section{REFERENCES}

Antil JH (1984). Socially responsible consumers: profile and implications for public policy, J. Macromarketing, 1:18-39.

Araújo CA (2006).Bibliometria: evolução históricae questões atuais, Em Questão, 12(1): 11-32.

Banks MG (2006). An Extension of the Hirsch index: indexing scientific topics and compounds. Disponível em: www.arxiv.org/abs/physics/0604216. Acesso em: 07/07/2010.

Bar-Ilan J (2008). Which h-index? A comparison of WoS, Scopus and Google Scholar, Scientometrics, 74(2): 257-271.

Bar-llan J (2010). Web of Science with the Conference Proceedings Citation Indexes: the case of computer science. Scientometrics, 83: 809-824.

Chaharbaghi K, Willis R (1999). The study and practice of sustainable development. Eng. Manag. J., 9(1): 41-48.

Costanza R, Daly HE, Bartholomew JA (1991). Goals agenda and policy recommendations for ecological economics, Ecological Economics. In: Costanza, R.(Ed.), The science and management of sustainability, New York: Columbia University Press.

Dias R (2008). Marketing Ambiental: ética, responsabilidade social e competitividade nos negócios. São Paulo: Atlas.

Ehrenfeld J (2001). Designing 'sustainable' product/service systems, Second International Symposium on Environmentally Conscious Design and Inverse Manufacturing, Tokyo, pp. 12-23.

Farrell A (1995). Sustainability theory and the design of knowledge tools. Foundations and Applications of General Science Theory, pp. 120-129.

Fonseca EN (1986). Bibliometria: teoria e prática. São Paulo: Cultrix.

Foresti N (1989). Estudo da contribuição das revistas brasileiras de biblioteconomia e ciência da informação enquanto fonte de referência para a pesquisa. 1989. Dissertação de Mestrado apresentada ao Departamento de Biblioteconomia da Universidade de Brasília, UnB, Brasília.

Funtowicz S, O'Connor M (1999). Science for sustainable development. Int. J. Sustain. Dev., 2: 3.

Garfield E (1963). Science Citation Index. Science Citation Index 1961, v. 1. Disponível em: http://garfield.library.upenn.edu/papers/80.pdf. Acesso em 28/06/2010.

Gladwin TN, Kennelly JJ, Krause TS (1995). Shifting paradigms for sustainable development: implications for management theory and research. Acad. Manag. Rev., 20: 874-907.

Gonçalves-Dias, SLF, Teodósio ASS, Barbieri JC (2007). Desafios e perspectivas da sustentabilidade: caminhos e descaminhos na gestão empresarial, IX ENGEMA, 2007, Curitiba.
Grubler A (2000). Managing the global environment. Environ. Sci. Technol., 34: 184-187.

Guide V Jr., Daniel R, Teunter RH, Van Wassenhove LN (2003). Matching demand and supply to maximize profits from remanufacturing. Manuf. Serv. Oper. Manag., 5: 303-316.

Guide VDR Jr., Van Wassenhove LN (2001). Managing product returns for remanufacturing. Production Oper. Manag., 10: 142-155.

Hauschild M, Wenzel H, Alting L (1999). Life cycle design: a route to the sustainable industrial culture? Manuf. Technol., 48: 393-396.

Hirsch JE (2005). An index to quantify an individual's scientific research output, Proceedings of the National Academy of Sciences of the United States of America (PNAS), California, 102(46): 16569-16572.

Howarth G, Hadfield M (2003). Sustainable product development thinking and assessment: a practical approach, design and manufacture for sustainable development. Ed. Cambridge, UK, Professional Engineering Publishing Limited, pp. 181-192.

Kates RW (1994). "Sustaining life on the earth," Sci. Am., 271(4): 114.

Kates RW, Clark WC, Corell JR, Hall M, Jaeger CC, Lowe I, McCarthy JJ, Schellnhuber HJ, Bolin B, Dickson NM, Faucheux S, Gallopin GC Gruebler A, Huntley B, Jäger J, Jodha NS, Kasperson RE, Mabogunje A, Matson P, Mooney H, Moore III B, O'Riordan T, Svedin $U$ (2000). Sustainability science. Research and Assessment Systems for Sustainability Program Discussion Paper 2000-33. Cambridge, MA: Environment and Natural Resources Program, Belfer Center for Science and International Affairs, Kennedy School of Government, Harvard University.

Kelly D, Jennions MD (2006). The $\mathrm{h}$ index and career assessment by numbers. Trends Ecol. Evol., 21(4): 167-170.

Kinnear T, Taylor JR, Ahmed S (1974). Ecologically concerned consumers: who are they? J. Mark., 38:20-24.

Madruga LRRG, Silva TN (2008). A localização das publicações e a identificação de tópicos quentes em sustentabilidade: uma primeira aproximação usando o Web of Science, XIV SIMPEP, 2008, São Paulo.

Moore III B (2000). Sustaining Earth's life support systems: the challenge for the next decade and beyond. Global Change News Letter, 41: 1-2.

Mosovsky J, Dickinson D, Morabito J (2000). Creating competitive advantage through resource productivity, eco-efficiency, and sustainability in the supply chain, International Symposium on Electronics and the Environment, San Francisco, California, pp. 230237.

O'Riordan T (2000). Environmental science on the move, Environmental Science for Environmental Management, pp. 1-27.

Sachs I (1993). Estratégias de transição para o século XXI: desenvolvimento e meio ambiente. São Paulo: Studio Nobel, Fundap.

Schmidheiny S (1992). The business logic of sustainable development. Columbia J. World Bus., 27:18-24.

Sharma A, lyer GR, Mehrotra A, Krishnan R (2010). Sustainability and business-to-business marketing: a framework and implications. Ind. Mark. Manag., 39: 330-341.

Thomson Scientific (2010). Web of Science. Disponível em: http://scientific.thomson.com/products/wos/. Acesso em: 28/06/2010.

World Commission on Environment and Development (1987). Our common future. Oxford, UK: Oxford University Press. 